удк 616.314.163

\title{
ПРИЧИНЫ ВОЗНИКНОВЕНИЯ И ПРОГНОЗ СОХРАНЕНИЯ ЗУБОВ С ЯТРОГЕННЫМИ ПЕРФОРАЦИЯМИ ПРИ УСТАНОВКЕ ШТИФТОВЫХ КОНСТРУКЦИЙ И ВКЛАДОК
}

\author{
Р.С. Назарян, Н.А. Щеблыкина, Т.А. Колесова, Ю.В. Фоменко, Н.В. Голик \\ Харьковский национальный медицинский униВерситет
}

\begin{abstract}
Значительная потеря твердых тканей зуба может привести к перелому зуба. Необходимой профилактикой переломов зубов является их армирование штифтовыми конструкциями или вкладками. При подготовке корневого канала к припасовке и фиксации штифта или вкладки возможны осложнения в виде перфорации стенки корня. Во всех случаях ятрогенных перфораций, исходя из анализа рентгенограмм, причиной явилось грубое препарирование твердых тканей зуба под армирующую конструкцию. Неправильное направление турбинного бора или развертки, которое не совпадает с основным ходом просвета канала, и применение излишних усилий ведет к созданию ложного хода. Также ошибкам при установке армирующих конструкций могут способствовать плотные силлеры, например, резорцин-формалиновая смесь. В таком случае довольно сложно тактильно отличить силлер и дентин корня. Задачу формирования пространства под штифрт усложняет отсутствие гуттаперчевого штифрта в корневом канале. Плохое знание анатомии зуба также может привести к ошибкам и удалению зуба.

КлючеВые слова: ятрогенная перфорация, армирование зуба, анкерный штифт, Вкладка, устранение перорорации.
\end{abstract}

На этапе обеспечения доступа к корневым каналам при эндодонтическом лечении происходит значительная потеря твердых тканей зуба с последующим ослаблением его структур. Так, в случае проведенного эндодонтического лечения зуба с полостью типа МОД приходится считаться с утратой механической стойкости на уровне около $82 \%$ [1]. Также ослабление механических свойств дентина может возникнуть вследствие применения средств для ирригации корневых каналов, хелатирующих веществ или кальцийсодержащих препаратов. Значительная потеря твердых тканей зуба может привести к перелому зуба. Необходимой профилактикой переломов зубов является их армирование штисртовыми конструкциями или вкладками. При подготовке корневого канала к припасовке и фриксации штифта или вкладки возможны осложнения в виде перфорации стенки корня.

Перфорация - связь между корневым каналом и внешней поверхностью корня, возникшая ятрогенно или вследствие патологической резорбции $[1,2]$.

По данным литературы ятрогенные перфорации встречаются в 2-12\% зубов [1-4]. Перфорация способствует проникновению микрофрлоры по корневому каналу в направлении периодонта, что при отсутствии лечебных мероприятий может привести к удалению зуба.

Факторы, наиболее влияющие на прогноз сохранения зуба с перфорацией: давность, степень бак- териальной контаминации, наличие лизиса костной ткани, уровень перфорации, ее размер и форма. Чем дольше период без герметичного закрытия перфорации, тем больше вероятность инфицирования и резорбции кости. Лечение давних перфораций, обильно обсемененных микрофрлорой, имеет сомнительный прогноз. Локализация перфорации вблизи поверхности альвеолярного отростка приводит к быстрому инфицированию из десневой борозды. Поэтому прогноз лечения таких перфораций более неблагоприятный, чем перфораций, находящихся глубже в корневом канале. Осложняющим фрактором может быть наличие зубодесневого кармана. Чем больше размер перфорации, тем более неблагоприятный прогноз, так как сложнее выполнять уплотнение материала [1, 2, 5, 6].

Цель исследования. Определение частоты встречаемости и возможных причин ятрогенных перфораций при армировании зубов штифртовыми конструкциями и вкладками, а также разработка профилактических мероприятий по предупреждению возникновения осложнений при восстановлении зубов после эндодонтического лечения на основании клинико-рентгенологических данных.

Материал и методы исследования. Было проведено рентгенологическое обследование 928 первичных пациентов, обратившихся в клинику за последние 5 лет. Выявляли штифттовые конструкции и вкладки, 
продольная ось которых не совпадала с основным направлением корневого канала, либо верхушки армирующих конструкций рентгенологически располагались близко к периодонту (рис. 1) или выходили за пределы корня (рис. 2).

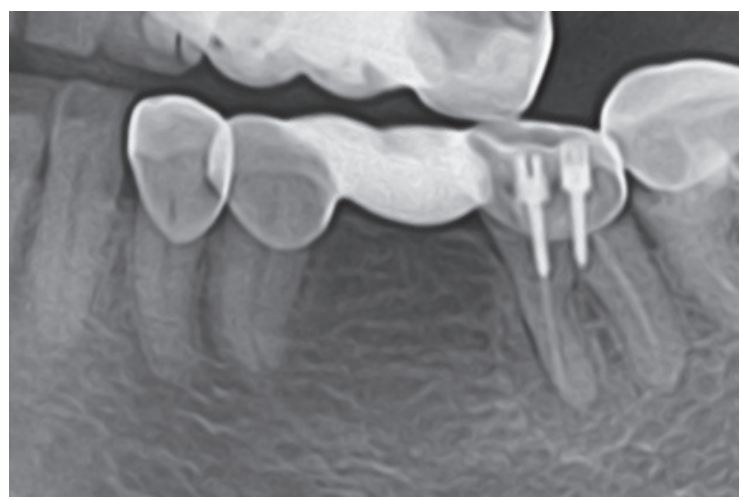

Рис. 1. Анкерный штифтт в дистальном корне зуба 37 установлен не по ходу канала, а в направлении бифуркации и близко подходит к периодонту. Вероятность перфорации высока

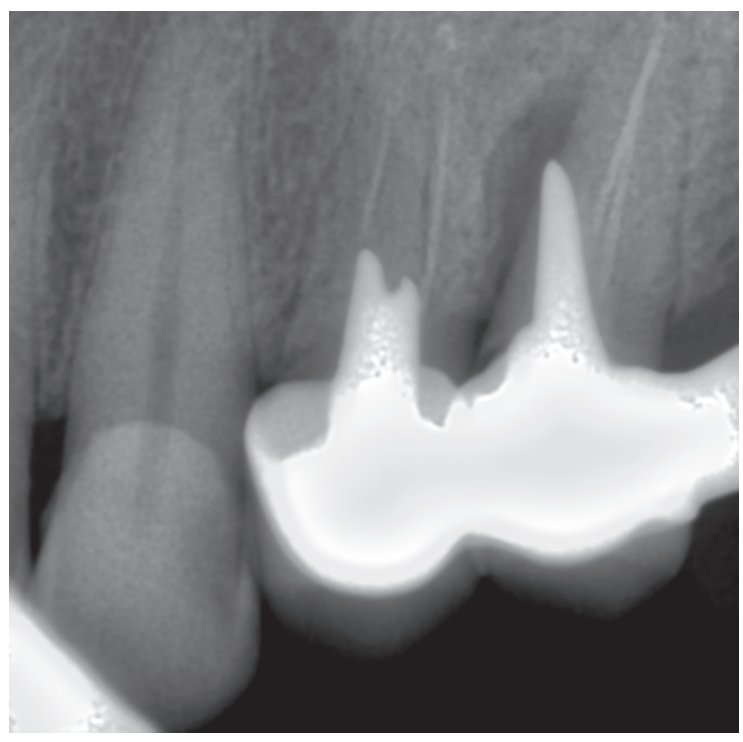

Рис. 2. Вкладка в зубе 25 установлена в искусственно созданный ход с выведением ее верхушки

в периодонт. Перфорация инфицирована, имеются рентгенологические признаки лизиса костной ткани

При проведении последующего лечения определяли метод и материал, с помощью которого ранее был запломбирован корневой канал. Перфорации герметизировали стекло-йономерным цементом с помощью операционного микроскопа Global G6. Bсе пациенты находятся под диспансерным наблюдением.

Результаты и их обсуждение. Проанализировано 928 ортопантомограмм первичных пациентов в возрасте от 18 до 76 лет. Ятрогенные перфорации корней были обнаружены в 31 зубе. Из анамнеза установлено, что зубы были пролечены в период от 6 месяцев до 14 лет назад. В 26 (83,8\%) перфорациях установлены штифртовые конструкции, в 5 (16,2\%) - вкладки. В 7 (22,6\%) случаях пациенты обращались с жалобами на наличие свища, боли и периодические отеки в области зубов с перфорациями. В остальных случаях $(77,4 \%)$ наличие перфораций определены рентгенологически, и пациенты жалоб не предъявляли.

Корневые каналы в зубах с перфорациями были запломбированы резорцин-фрормалиновым методом - $19(61,3 \%)$ зубов, ЦОЭ без гуттаперчи - 8 (25,8\%) зубов, ЦОЭ с гуттаперчей - $3(9,7 \%)$ зуба, полимерный силлер с гуттаперчей - 1 зуб (3,2\%).

Во всех случаях ятрогенных перфораций удаляли армирующие конструкции и цемент, фиксировавший штифт либо вкладку. Всем пациентам с ятрогенными перфорациями корней было проведено повторное эндодонтическое лечение.

В сомнительных случаях, когда не было полной уверенности в наличии перфорации корня, но рентгенологически присутствовали признаки локального лизиса кости, с согласия пациента, штифт либо вкладку удаляли и осматривали предполагаемый дефект с помощью операционного микроскопа Global G6.

После уточнения диагноза проводили закрытие перфораций в зависимости от показаний временным или постоянным пломбировочным материалом.

Если после удаления штифта либо вкладки не наблюдали экссудата, и пациент не предъявлял жалоб, то закрытие перфорации проводили в то же посещение.

Если из перфорационного отверстия получали обильное выделение гнойно-кровянистого экссудата, ложный ход заполняли рассасывающимся кальцийсодержащим материалом. В следующее посещение при отсутствии жалоб и отделяемого перфорацию герметизировали при помощи стекло-йономерного цемента.

Пациенты с сохраненными зубами были поставлены на диспансерное наблюдение. Контрольные снимки проводили каждые 3-6 мес.

В случае неуспеха терапевтического лечения прибегали к хирургическим методам лечения - гемисекции, ампутации корня. При отрицательной динамике в лечении либо при невозможности удалить армирующую конструкцию в $6(19,4 \%)$ случаях зубы были удалены (рис. 3, 4).

В $25(80,6 \%)$ случаях армирующие конструкции были извлечены (рис. 5, 6), а перфорации закрыты стекло-йономерным цементом (рис. 7).

Отсутствие симптоматики не всегда говорит о благополучии процесса. Попытка ортоградной герметизации корневого канала не во всех случаях приводит к стабилизации процесса и отсутствию жалоб в отдаленные сроки (рис. 8).

Обычно, если перфорацию закрывают в момент ее возникновения, то достигают наилучших результатов. Однако во всех исследованных случаях перфорации не были вовремя замечены и, соответственно, не были приняты меры по устранению осложнений, что привело к длительно существовавшим инфицированным процессам.

Таким образом, во всех случаях ятрогенных перфораций, исходя из анализа рентгенограмм, 


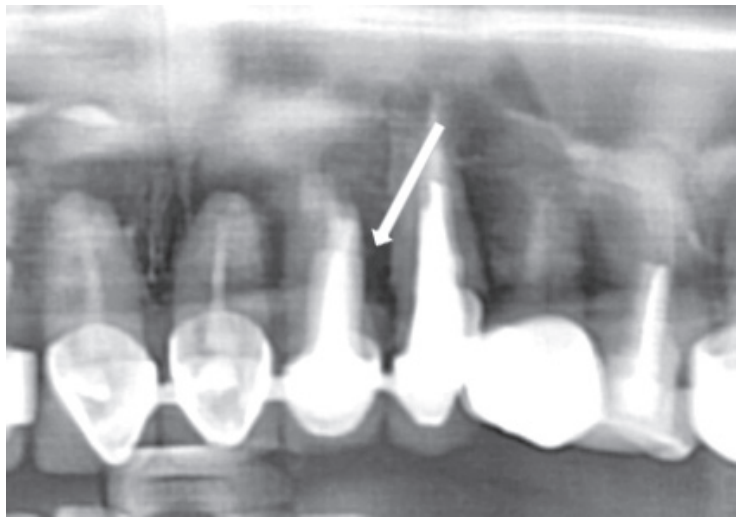

Рис. 3. Рентгенологически - лизис костной ткани в проекции перфорации латеральной поверхности бокового резца

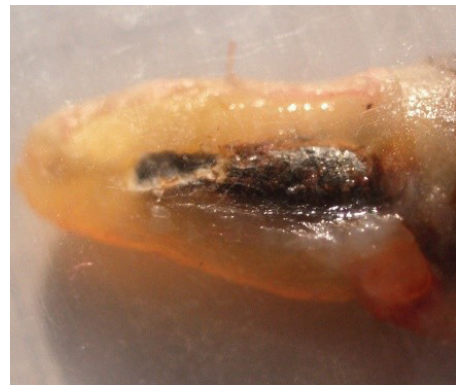

Рис. 4. Обширная латеральная перфорация. Невозможность удалить вкладку и ноющая боль в области причинного зуба привели к его удалению

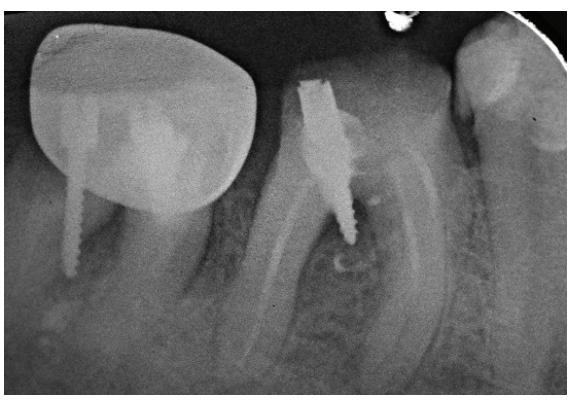

Рис. 5. Зубы 46, 47 с ятрогенными перфорациями и установленными в них анкерными штифртами. Из зуба 46 был извлечен штифт. Зуб 47 был удален

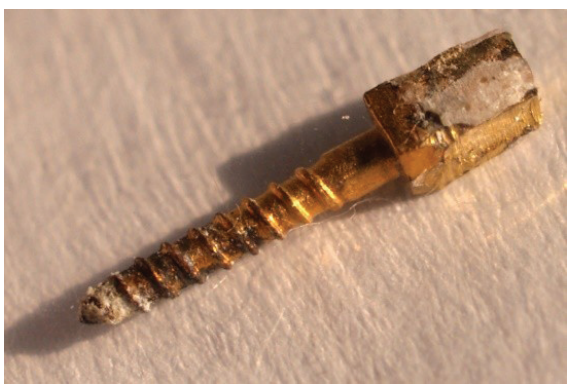

Рис. 6. Анкерный штифтт из зуба 46, который был установлен 14 лет назад и пациентку не беспокоил

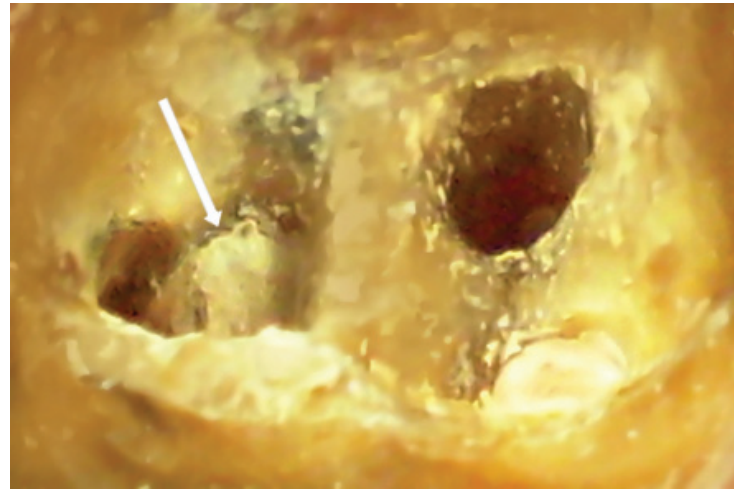

Рис. 7. Дно полости зуба 46. На медиальной поверхности дистального корня перфорация закрыта СИЦ

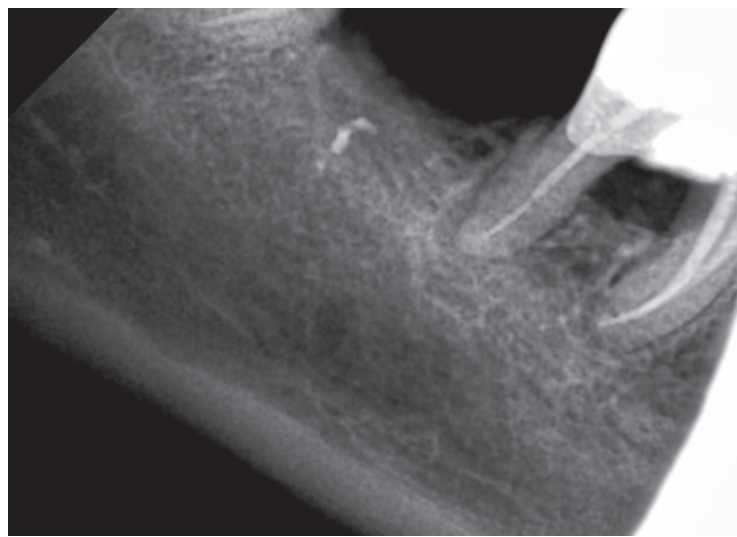

Рис. 8. Зуб 46 через 2 года после закрытия перфорации. В межкорневой области - горизонтальная резорбция костной ткани. Зуб пациентку не беспокоит

причиной явилось грубое препарирование твердых тканей зуба под армирующую конструкцию. Неправильное направление турбинного бора или развертки, которое не совпадает с основным ходом просвета канала и применение излишних усилий ведет к созданию ложного хода. Часто так происходит потому, что восстановление зуба после эндодонтического лечения осуществляет стоматолог-ортопед, который в силу специфики работы редко имеет дело с направлением корневых каналов. Также ошибкам при установке армирующих конструкций могут способствовать плотные силлеры, которыми стоматологтерапевт пломбирует корневые каналы, например, резорцин-формалиновая смесь. В таком случае довольно сложно тактильно отличить силлер и дентин корня. Задачу формирования пространства под штифт усложняет отсутствие гуттаперчевого штифрта в корневом канале. И, наконец, нельзя не учитывать плохое знание анатомии зуба, которое также может привести к ошибкам и удалению зуба.

Практические рекомендации по профилактике перфораций при постэндодонтическом восстановлении зубов:

- врач-терапевт, который проводит эндодонтическое лечение зуба, может самостоятельно создать пространство под штифртовую конструкцию, что весьма облегчит работу стоматолога-ортопеда; 
- обязательное введение при обтурации корневого канала гуттаперчи, как этого требует современная концепция эндодонтического лечения, также позволит ортопеду тактильно ощутить разницу между дентином корня и пространством корневого канала. К тому же гуттаперча при вращении инструмента разогревается и легко выводится из канала, что также сводит к минимуму вероятность ошибки.

Дальнейшие исследования в направлении расширения междисциплинарного взаимодействия в стоматологии являются перспективными.

\section{Литература}

1. Мацей Жаров. ЭндоПрактика. Восстановление зубов после эндодонтического лечения / Мацей Жаров, Камилло Д'Арканджэло, Луис Антонио Филиппе [и др.]. Пер. с польск. - Львов: Галдент, 2014. - 336 с.

2. Clinical success in endodontic retreatment. Stephane Simon Wilhelm-Joseph Pertot. Paris: Quintessence book, 2009. $-144 \mathrm{p}$.

3. Рогожников А.Г. Механический анализ штифтовой конструкции с ионно-плазменным напылением / А.Г. Рогожников, В.Ю. Кирюхин, Г.И. Рогожников / / РЖ Биомеханики. - 2006. - Том 10. - № 2. - С. 64-79.

4. Шарин А.Н. Прогноз и отдаленные результаты применения штифртовых конструкций с опорой на депульпированные зубы / А.Н. Шарин Н.А. Бондаренко / / Маэстро стоматологии. - 2016. - № 1(61). С. $32-36$.

5. Повторное эндодонтическое лечение / Мариу Луис Зуолу, Даниэль Керлакян, Жозе Эдуарду де Меллу-мл [и др.]; пер. с англ. А. Островского. - М.: ООО «Азбука стоматолога», 2016. - 318 с.

6. Роудз Джон С. Повторное эндодонтическое лечение: консервативные и хирургические методы / Джон С. Роудз. - М.: МЕДпресс-информ, 2009. - 216 с.

\section{Р.С. Назарян, Н.А. Щебликіна, Т.О. Колесова, Ю.В. Фоменко, Н.В. Голік}

\section{ПРИЧИНИ ВИНИКНЕННЯ I ПРОГНОЗ ЗБЕРЕЖЕННЯ ЗУБІВ 3 ЯТРОГЕННОЮ ПЕРФОРАЦІЄЮ ПРИ ВСТАНОВЛЕННІ ШТИФТОВИХ КОНСТРУКЦІЙ І ВКЛАДОК}

Значна втрата твердих тканин зуба може привести до перелому зуба. Необхідною профілактикою переломів зубів $€$ їх армування штифтовими конструкціями або вкладками. При підготовці кореневого каналу до фріксації штифрта або вкладки можливі ускладнення у вигляді перфорації стінки кореня. У всіх випадках ятрогенних перфорацій, виходячи з аналізу рентгенограм, причиною стало грубе препарування твердих тканин зуба під армуючу конструкцію. Неправильний напрямок турбінного бора або розгортки, яка не збігається з основним ходом просвіту каналу, і застосування зайвих зусиль веде до створення помилкового ходу. Також помилкам при установці армуючих конструкцій можуть сприяти щільні силери, наприклад, резорцин-формалінова суміш. У такому випадку досить складно тактильно відрізнити силер і дентин кореня. Формування простору під штифрт ускладнює відсутність гутаперчевого штифрта в кореневому каналі. Погане знання анатомії зуба також може привести до помилок і видалення зуба.

Ключові слова: ятрогенна перфорачія, армуВання зуба, анкерний штифрт, Вкладка, усунення nepфopauii.

\section{R.S. Nazaryan, N.A. Scheblykina, T.A. Kolesova, Yu.V. Fomenko, N.V. Golik}

\section{THE CAUSES AND PROGNOSIS OF TEETH PRESERVATION WITH IATROGENIC PERFORATIONS DURING THE INSTALLATION OF PINS AND INLAYS}

At the stage of providing access to the root canals during endodontic treatment there is a significant loss of the tooth hard tissues, followed by weakening of its structures. So, in the case of endodontic treatment of a tooth with a cavity of the MOD type, one has to reckon with the loss of mechanical stability at the level of about $82 \%$. Also, the weakening of the mechanical properties of dentin may occur due to the use of solutions for root canals irrigation, chelating agents or calcium-containing preparations. Significant loss of hard tooth tissue can lead to tooth fracture. The necessary prevention of fractures of the teeth is their reinforcement with pins or inlays. When preparing the root canal for fitting and fixing the pin or inlays, complication, such as perforation of the root wall, is possible.

Perforation is the connection between the root canal and the outer surface of the root, which has appeared iatrogenic or due to pathological resorption. According to the literature, iatrogenic perforations are found in $2-12 \%$ of teeth. Perforation promotes the penetration of microflora along the root canal in the direction of the periodontium, which, in the absence of therapeutic measures, can lead to tooth extraction.

The factors that most affect the prognosis for preserving a perforated tooth: age of perforation, the degree of bacterial contamination, the presence of bone lysis, the level of perforation, its size and shape. The longer period without tight closure of perforation, the greater likelihood of infection penetration and bone resorption is. Localization of perforation near the surface of the alveolar process leads to rapid infection of the gingival sulcus. Therefore, the prognosis for treating such perforations is more unfavorable than perforations deeper in the root canal. A complicating factor may be the presence of a tooth-gingival pocket. The larger the size of the perforation, the more unfavorable is forecast, since it is more difficult to perform compaction of the material. 
Purpose of the study. Determination of the occurrence frequency and possible causes of iatrogenic perforations in the reinforcement of teeth with pins and inlays, as well as the development of preventive measures to prevent complications in the restoration of teeth after endodontic treatment on the basis of clinical and radiological data.

Material and research methods. X-ray examination of 928 primary patients who applied to the clinic for the last 5 years was performed. Pins and inlays were detected, the longitudinal axis of which did not coincide with the main direction of the root canal, or the tops of the reinforcing structures were radiographically close to the periodontal ligament, or went beyond the root. After the diagnosis was clarified, the perforations were closed, depending on the indications, with a temporary or permanent filling material. If, after removing the pin or tab, no exudate was observed and the patient did not complain, the perforation was closed at the same visit. If a plentiful discharge of purulent-bloody exudate was obtained from the perforation hole, the false passage was filled with absorbable calcium-containing material. On the next visit, in the absence of complaints, perforations were sealed with glassionomer cement. X-rays were taken every 3-6 months. In case of failure of therapeutic treatment, surgical methods of treatment - hemisection, root amputation were carried out. In case of negative dynamics in treatment or in case of impossibility to remove the reinforcing structure teeth were removed. Usually, if the perforation is closed at the moment of its occurrence, then the best results are achieved. However, in all cases investigated, the perforations were not noticed in time and, accordingly, no measures were taken to eliminate the complications, which led to longexisting infected processes.

Results. In all cases of iatrogenic perforations, based on the analysis of radiographs, the reason was the rough preparation of hard tooth tissues for a reinforcing structure. The wrong direction of the turbine drill, which does not coincide with the main course of the channel and the application of excessive effort leads to the creation of a false passage. In case of root canal obturation with resorcin-formalin mixture, it is quite difficult to distinguish tactilely sealer and dentin of the root. The task of forming the space for a pin complicates the absence of a gutta-percha pin in the root canal. And finally, it is impossible not to take into account the poor knowledge of the anatomy of the tooth, which can also lead to errors and tooth extraction.

Practical recommendations for the prevention of perforations in the post-endodontic restoration of teeth:

- a general practitioner, who performs endodontic treatment of a tooth can independently create a space for a pin, which will greatly facilitate the work of a prosthetist;

- mandatory introduction of gutta-percha during the obturation of the root canal, as required by the modern concept of endodontic treatment, will also allow the prosthetist to tactilely sense the difference between the root dentin and the root canal space. In addition, when instrument is rotated, gutta-percha is heated and easily removed from the channel, which also minimizes the probability of error.

Further studies in the direction of expanding interdisciplinary interactions in dentistry are promising.

Keywords: iatrogenic perforation, tooth reinforcement, anchor pin, inlay, perforation elimination.

\section{Інформація про авторів}

Назарян Розана Степанівна - професор, завідувач кафедри стоматології дитячого віку, дитячої щелепнолицевої хірургії та імплантології Харківського національного медичного університету

Адреса для кореспонденції: 61022, Україна, м. Харків, просп. Науки, 4

e-mail: rosnazaryan@gmail.com

ORCID: 0000-0002-0005-8777

Фоменко Юлія Володимирівна - доцент кафедри стоматології дитячого віку, дитячої щелепно-лицевої хірургії та імплантології Харківського національного медичного університету

ORCID: 0000-0002-9411-4142 